\section{Pacific Northwest}

National Laboratory

Operated by Battelle for the

U.S. Department of Energy

\title{
Experimental Plan: \\ 300 Area Treatability Test: In Situ \\ Treatment of the Vadose Zone and Smear \\ Zone Uranium Contamination by \\ Polyphosphate Infiltration
}

D. M. Wellman

E.M. Pierce

M. Oostrom

J. S. Fruchter

August 2007

Prepared for the U.S. Department of Energy

under Contract DE-AC05-76RL01830

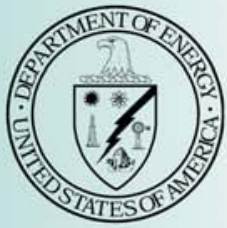




\title{
DISCLAIMER
}

This report was prepared as an account of work sponsored by an agency of the United States Government. Neither the United States Government nor any agency thereof, nor Battelle Memorial Institute, nor any of their employees, makes any warranty, express or implied, or assumes any legal liability or responsibility for the accuracy, completeness, or usefulness of any information, apparatus, product, or process disclosed, or represents that its use would not infringe privately owned rights. Reference herein to any specific commercial product, process, or service by trade name, trademark, manufacturer, or otherwise does not necessarily constitute or imply its endorsement, recommendation, or favoring by the United States Government or any agency thereof, or Battelle Memorial Institute. The views and opinions of authors expressed herein do not necessarily state or reflect those of the United States Government or any agency thereof.

\author{
PACIFIC NORTHWEST NATIONAL LABORATORY \\ operated by \\ BATTELLE \\ for the \\ UNITED STATES DEPARTMENT OF ENERGY \\ under Contract DE-AC05-76RL01830
}

Printed in the United States of America
Available to DOE and DOE contractors from the Office of Scientific and Technical Information,
P.O. Box 62, Oak Ridge, TN 37831-0062;
ph: (865) 576-8401
fax: (865) 576-5728
email: reports@adonis.osti.gov

\begin{abstract}
Available to the public from the National Technical Information Service, U.S. Department of Commerce, 5285 Port Royal Rd., Springfield, VA 22161 ph: (800) 553-6847 fax: (703) 605-6900

email: orders@ntis.fedworld.gov

online ordering: http://www.ntis.gov/ordering.htm
\end{abstract}

This document was printed on recycled paper. 


\title{
Experimental Plan:
}

\section{Area Treatability Test: In Situ Treatment of the Vadose Zone and Smear Zone Uranium Contamination by Polyphosphate Infiltration}

\author{
D. M. Wellman \\ E. M. Pierce \\ M. Oostrom \\ J. S. Fruchter
}

August 2007

Prepared for

the U.S. Department of Energy

under Contract DE-AC05-76RL01830

Pacific Northwest National Laboratory

Richland, Washington 99352 


\section{Summary}

For fiscal year 2006, the U.S. Congress authorized \$10 million to Hanford for “.... analyzing contaminant migration to the Columbia River, and for the introduction of new technology approaches to solving contamination migration issues." These funds are administered through the U.S. Department of Energy Office of Environmental Management (specifically, EM-22). After a peer review and selection process, nine projects were selected to meet the objectives of the appropriation. As part of this effort, Pacific Northwest National Laboratory (PNNL) is performing bench-scale and field-scale treatability testing to determine the efficacy of using polyphophate injection into the saturated zone to treat groundwater uranium contamination at the Hanford 300 area.

Subsequently, an additional \$2 million was made available in FY 2007 from EM-22 to pursue followon projects. One of the follow-on projects selected is bench-scale treatability testing designed to evaluate whether the polyphosphate process could be modified so that it is infiltrated either from ground surface or some depth of excavation to stabilize, in situ, uranium within the deep vadose and zone of water-table fluctuation (i.e., smear zone) above the 300 Area aquifer. This technology works by stabilizing soluble uranium phases contained within the vadose and smear zone as stable uranium phosphate minerals. This effort will compliment the current 300 Area treatability test being conducted within the saturated zone (e.g., 300 Area aquifer) to evaluate the efficacy of using polyphosphate injection to treat uraniumcontaminated groundwater in situ. Source treatment in the deep vadose zone will accelerate the natural attenuation of uranium to thermodynamically stable uranium-phosphate minerals, enhancing the performance of the proposed polyphosphate remediation within the 300 Area aquifer. Data obtained from this study will be used to develop implementation cost estimates, identify implementation challenges, and investigate the capability of the technology to meet remedial objectives. This information will be used to establish the viability of the method and determine how best to implement the technology in the field.

The objectives of the treatability test are to 1) quantify the retardation of polyphosphate and its degradation products as a function of water content, 2) determine the rate of polyphosphate degradation under unsaturated conditions, 3) develop an understanding of the mechanism of autunite formation via the reaction of solid phase calcite-bound uranium and aqueous polyphosphate remediation technology, 4) develop an understanding of the transformation mechanism, the identity of secondary phases, and the kinetics of the reaction between uranyl-carbonate and -silicate minerals with the polyphosphate remedy under solubility-limiting conditions, 5) quantify the extent and rate of uranium released and immobilized based on the infiltration rate of the polyphosphate remedy and the effect of and periodic wet-dry cycling on the efficacy of polyphosphate remediation for uranium in the vadose zone and smear zone, and 6) quantify equilibrium solubility values for autunite under hydraulically unsaturated conditions, allowing accurate prediction of the long-term stability of autunite. Results of intermediate-scale testing will quantify the transport of polyphosphate and degradation products and yield degradation rates at a scale that is bridging the gap between the small-scale unsaturated flow apparatus studies and the field scale. These results will be used to test and verify a site-specific, variable-saturation, reactive-transport model and to aid in the design of a pilot-scale field test of this technology. In particular, the infiltration approach and monitoring strategy of the pilot test would be primarily based on results from intermediate-scale testing. Results from this experimental plan will be documented in a PNNL report. 


\section{Acronyms}

ASTM

DOE

EDS

EMSL

EPA

FFF-ICP-MS

HASQARD

HPA

HR-TEM

IC-MS

ICP-OES

ICP-MS

MCL

NMR

NQARD

PFBA

PNNL

${ }^{31} \mathrm{P}$ NMR

PUF

QC

SBMS

SEM

SFTL

TEM

UFA

XRD
American Society of Testing Materials

U. S. Department of Energy

energy dispersive spectroscopy

Environmental Molecular Science Laboratory

U. S. Environmental Protection Agency

Field flow fractionation-inductively coupled plasma-mass spectrometry

Hanford Analytical Services Quality Assurance Requirements Documents

Hydraulic Properties Apparatus

high resolution-transmission electron microscopy

ion chromatography-mass spectrometry

inductively coupled plasma-optical emission spectrometry

inductively coupled plasma-mass spectrometry

maximum concentration limit [in groundwater reports, $\mathrm{MCL}=$ maximum contaminant level]

nuclear magnetic resonance

Nuclear Quality Assurance Requirements Description

pentafluorobenzoic acid

Pacific Northwest National Laboratory

phosphorus-31 nuclear magnetic resonance

pressurized unsaturated flow

quality control

Standards-Based Management System

scanning electron microscopy

Subsurface Flow and Transport Laboratory

transmission electron microscopy

unsaturated flow apparatus

$\mathrm{x}$-ray diffraction 


\section{Contents}

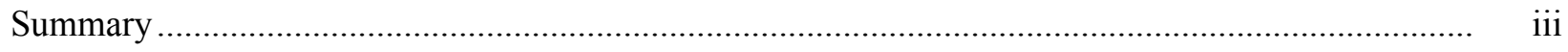

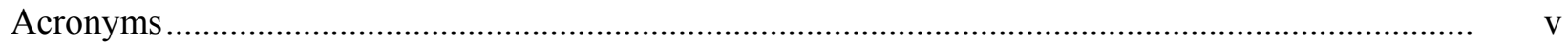

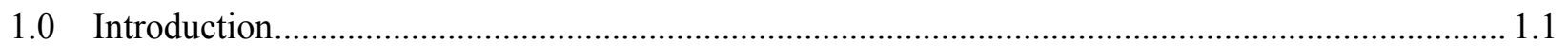

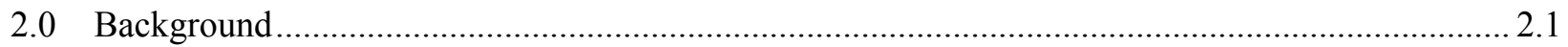

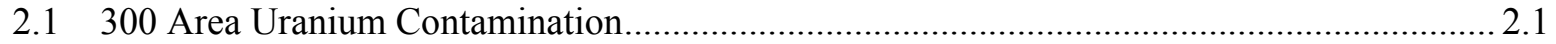

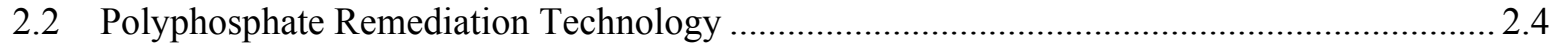

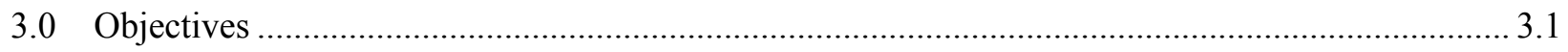

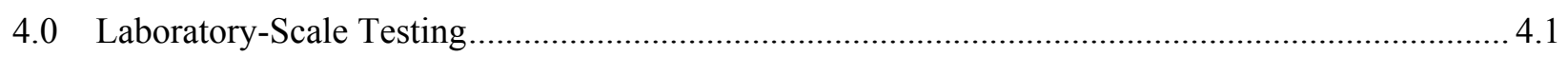

4.1 Behavior of Polyphosphate Amendment under Unsaturated Conditions .............................. 4.1

4.2 Interaction of Polyphosphate with Calcite-Bound Uranium.................................................... 4.3

4.3 Effect of Polyphosphate on Uranium Mineralogy ............................................................. 4.5

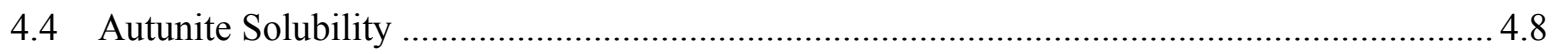

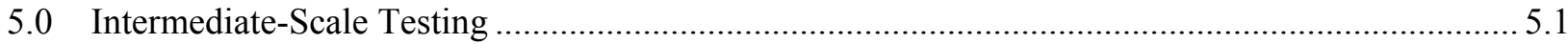

5.1 Effects of Sediment Type and Infiltration Characteristics on Vadose Zone Polyphosphate

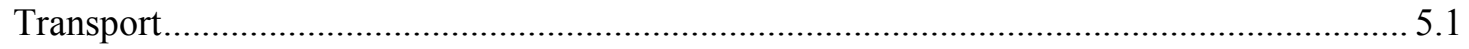

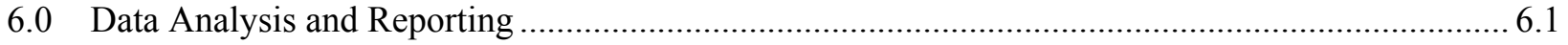

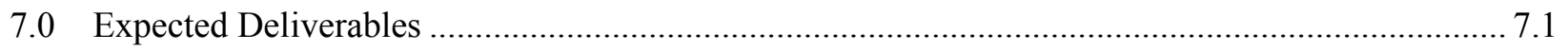

8.0 Quality Assurance, ES\&H, and Waste-Management Requirements ......................................... 8.1

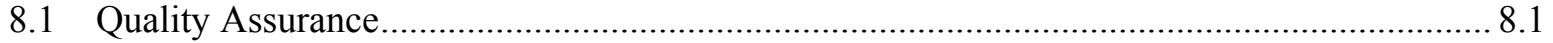

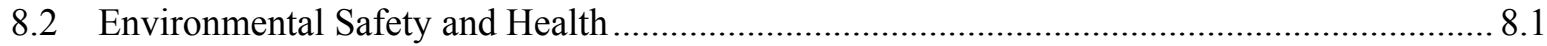

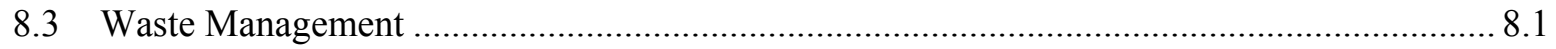

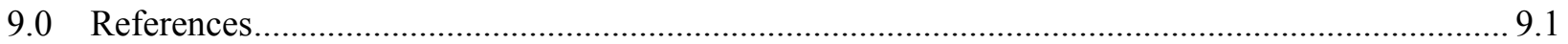




\section{Figures}

2.1. Map of the Hanford Site

2.2. Schematic Depicting the 300-FF-5 Operable Unit Geology and Proposed Treatability Test of Polyphosphate to Sequester Uranium

2.3. Schematic Depicting the Step-Wise Hydrolysis of Sodium Tripolyphosphate

2.4. Hydrolysis Rate of Polyphosphate Molecules as a Function of $\mathrm{pH}$.

2.5. Experimental Release of Uranium and Breakthrough of Phosphorus in Columns at $68 \%$ Water Content With and Without Soluble Sodium Tripolyphosphate Amendments at a Concentration of $1000 \mathrm{ppm}$

4.1. Schematic of UFA Constant Flow Rotor and Rotating Seal Assembly......

4.2. Photo of PUF Column Assembly

\section{Tables}

4.1. Experimental Conditions for the Quantification of Polyphosphate Mobility as a Function of Water Content.

4.2. Conditions for Quantification of the Kinetic Interaction of Polyphosphate with Calcitebound Uranium

4.3. Experimental Conditions for Quantifying the Loading of Polyphosphate on Calcite

4.4. Experimental Conditions for Quantifying the Partitioning of Polyphosphate with Calcite

4.5. Experimental Conditions for Quantifying the Interaction of Polyphosphate with UraniumBearing Phases.

4.6. Experimental Conditions for Quantifying the Interaction of Polyphosphate with UraniumBearing Phases.

4.7. Polyphosphate Test Amendment Formulation.

8.1. Technical Procedures Used in Designing this Experimental Plan 


\subsection{Introduction}

This experimental plan covers work elements associated with laboratory optimization of the polyphosphate amendment formulation to immobilize uranium within the 300 Area vadose zone and smear zone. Polyphosphate treatment shows promise for reducing the concentration of dissolved uranium and for stabilizing uranium contained within vadose zone and smear zone sediments. The polyphosphate technology was selected for further testing during the 300-FF-5 Phase III Feasibility Study technology screening process. An initial feasibility study (DOE 1995) for the 300-FF-5 uranium plume considered hydraulic containment, slurry wall containment, and groundwater extraction as potential remedial action technologies. None were selected for interim action, and reducing contamination levels by natural processes was considered a viable alternative while source-removal actions continued.

Subsequent planning for a Phase III feasibility study focused on methods that would reduce the concentration of uranium in the aquifer, including multiple methods to immobilize uranium using chemical-based technologies. Based on this initial technology screening, the polyphosphate technology was identified as the best candidate for further evaluation and selected for treatability testing. A treatability test is currently ongoing to evaluate the efficacy of using polyphosphate injections to treat uranium-contaminated groundwater in situ. This technology is expected to decrease the current aqueous uranium concentration and mitigate the flow of contaminated groundwater to the river. However, remediation of the aquifer does not address a potential recalcitrant source of uranium located in the vadose zone and smear zone. Therefore, the focus of this investigation is to use a series of bench-scale and intermediate-scale laboratory experiments to evaluate the efficacy of using polyphosphate to immobilize uranium within the vadose zone and zone of water-table fluctuation (i.e., smear zone) above the 300 Area aquifer.

Source treatment in the vadose zone is expected to 1) accelerate the natural attenuation of uranium to thermodynamically stable uranium-phosphate minerals and 2) enhance the performance of the proposed polyphosphate remediation within the 300 Area aquifer. Data obtained from this study will be used to develop implementation cost estimates, identify implementation challenges, and investigate the capability of the technology to meet remedial objectives. This information will be used to establish the viability of the method and determine how best to implement the technology in the field. 


\subsection{Background}

This section provides background information on uranium contamination in the 300 Area and the selection of polyphosphate remediation technology for further site-specific evaluation and treatability testing. In 1996, a record of decision (EPA 1996) identified the following interim actions for remediation of the uranium contaminant plume beneath the site:

- Continued groundwater monitoring to determine how contaminant conditions may change with time

- Institutional controls to limit the use of groundwater.

Interim-action results have determined that uranium concentrations in the groundwater plume have been generally declining, but still persist at concentrations above the drinking water standard (remediation goal). Therefore, it is necessary to re-evaluate the remedy for uranium contamination because the rate of decrease in uranium concentrations is significantly different than the rate of decrease expected and used as a basis for the remedy selection in the current record of decision.

During the 300-FF-5 Phase III Feasibility Study technology screening process, the polyphosphate treatment was judged to be the most promising among five other active remedial technologies for uranium at this site for reducing the concentration of dissolved uranium, and it was selected for further testing.

\subsection{Area Uranium Contamination}

Facilities in the 300 Area of the Hanford Site were primarily involved with fabricating nuclear fuel for plutonium production, which included some research and development activities, during the period spanning the startup of Hanford reactors in 1944 through the late 1980s (Young and Fruchter 1991). The range of activities produced a wide variety of waste streams that contained chemical and radiological constituents (Gerber 1992; DeFord et al. 1994).

The 300-FF-5 Operable Unit, a groundwater operable unit, is located in the southeast portion of the Hanford Site and includes the water and solids that constitute the aquifer. The contaminated groundwater contained in this Operable Unit consists of contaminants at concentrations that exceed the U.S.

Environmental Protection Agency (EPA) standards for drinking water supplies. These contaminants were released from waste sites in three geographic sub-regions of the operable unit: the 300 Area, 618-11 burial ground, and 316-4 cribs/618-10 burial ground (Figure 2.1), during past-practice disposal activities. Uranium is the most prominent waste constituent remaining in the environment, and it has persisted in waste sites and groundwater during the years following the shutdown of most fuel-fabrication activities and the cessation of liquid-effluent disposal to the ground. Uranium in soluble form is of concern for chemical toxicity, as well as for radiological exposure, although the concentrations in groundwater for chemical toxicity are lower than those associated with exceeding radiological dose standards. Specific criteria on the toxicity to freshwater aquatic organisms are not currently established, so by default, the criteria for the protection of aquatic organisms are the same as those applied for the protection of human health. 


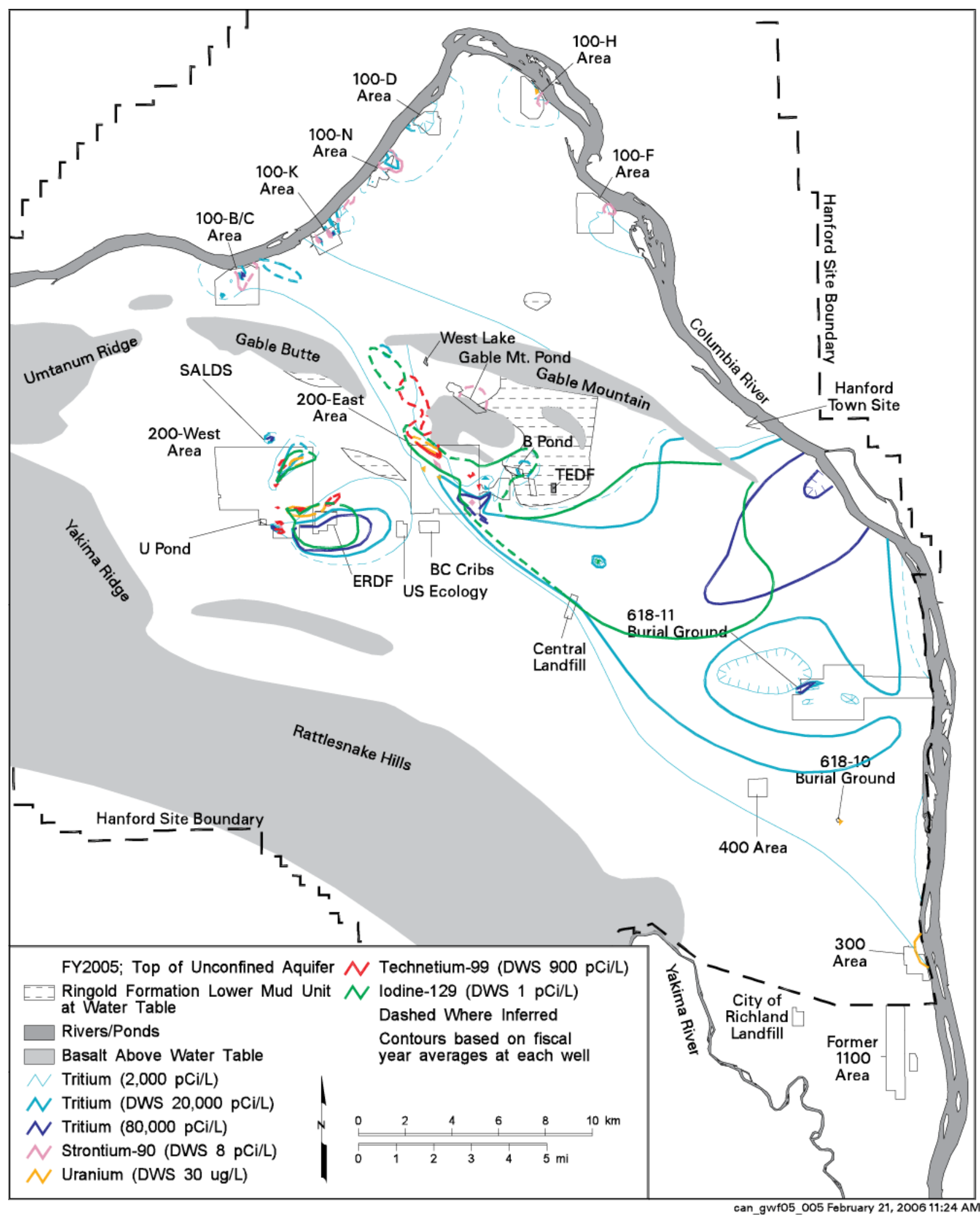

Figure 2.1. Map of the Hanford Site 
A groundwater plume containing uranium from past-practice discharges of liquid waste associated with nuclear fuel fabrication activities has persisted beneath the Hanford Site 300 Area for many years. The persistence of this plume is enigmatic for several reasons, including 1) discharges containing uranium-bearing effluent to ground-disposal sites ended in the mid-1980s, 2) contaminated soil associated with these waste sites was removed during the 1990s, with backfilling complete by early 2004, and 3) the aquifer is composed of highly transmissive fluvial sediment, suggesting rapid movement of groundwater. Also, a water-supply well located within the plume has been in operation since 1980, with no observable effect on the plume. The current conceptual site model assumes that re-supply of the plume is occurring, with continuing release from the vadose zone beneath waste sites, the smear zone zone, and possibly from aquifer solids, as source candidates.

Since the early 1990s, there has been extensive remediation of liquid-waste disposal sites and solidwaste burial grounds. As of March 2004, most liquid-waste disposal sites, which are located in the north half of the 300 Area, have been excavated and backfilled, and the ground surface has been restored. However, some unknown amount of contamination remains in the vadose zone beneath the lower extent of the excavation activities. Additional contamination may also remain beneath buildings and facilities in the southern portion of the 300 Area, which has not been decontaminated and decommissioned. Despite the cessation of uranium releases and the removal of shallow vadose zone source materials, the concentration of the uranium plume has not decreased as predicted. A treatability test is currently ongoing to evaluate the efficacy of using polyphosphate injections to treat uranium-contaminated groundwater in situ (Figure 2.2). This technology is expected to decrease the current aqueous uranium concentration and mitigate the flow of contaminated groundwater to the river. However, remediating the aquifer does not address a potential continuing source in the deep vadose and smear zones.

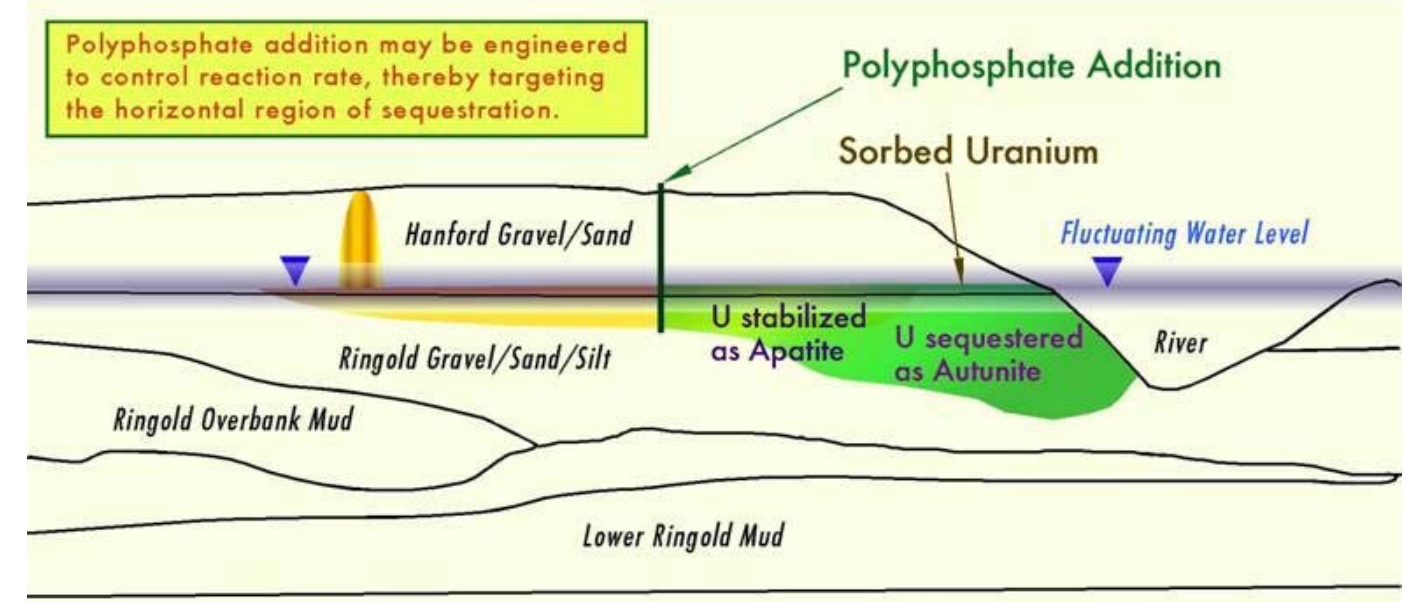

Figure 2.2. Schematic Depicting the 300-FF-5 Operable Unit Geology and Proposed Treatability Test of Polyphosphate to Sequester Uranium

Therefore, the focus of this investigation is to evaluate the efficacy of using the polyphosphate treatment technology to treat uranium contamination contained within the deep vadose zone and zone of water-table fluctuation (i.e., smear zone) above the 300 Area aquifer. Treatment of the potential source material contained in the deep vadose zone is expected to enhance the proposed polyphosphate remediation within the 300 Area aquifer. Data obtained from this study will be used to develop implementation cost estimates, identify implementation challenges, and investigate the capability of the 
technology to meet remedial objectives. This information will be used to establish the viability of the method and determine how best to implement the technology in the field.

\subsection{Polyphosphate Remediation Technology}

Numerous proposals have been made to remediate contaminated groundwater using phosphate amendment strategies (Arey et al. 1999; Moore et al. 2001; Seaman et al. 2001; Seaman et al. 2003; Wright et al. 1995). These proposals put forth the common idea to apply solid-phase phosphate (generally hydroxyapatite) directly to the contaminated soil or surface water or to use it as a trench fill emplaced in the pathway of migrating contaminant plumes. These strategies have merit and represent a feasible technology for near-surface treatment, yet cannot accomplish remediation of pore waters that are situated in deep aquifers or under conditions such as those found in the Hanford deep vadose zone and smear zone where the plume can extend 90 meters below ground surface (bgs).

Alternative strategies employ the use of water-soluble phosphate compounds that could be injected into the plume from strategically placed wells. However, one challenge about deploying a soluble phosphate amendment into the subsurface is the unwanted rapid precipitation of phosphate phases, which occlude the injection wells and pore space within the formation. Lee et al. (1995) proposed using tribasic sodium phosphate, $\mathrm{Na}_{3}\left(\mathrm{PO}_{4}\right) \cdot n \mathrm{H}_{2} \mathrm{O}$, as a chemical stabilizer for uranium and radiostrontium. However, even in relatively dilute groundwater solutions, there are enough dissolved cations to form Al-, Fe-, Ca-, and Na-phosphates. Nash and colleagues $(1993 ; 1994 ; 2000 ; 1998 a ; 1997 ; 1998 b ; 1999)$ attempted to circumvent this shortcoming by proposing that a water-soluble organophosphate compound, phytic acid, be injected into the contaminated groundwater. The key advantage of this method is that the hydrolyzation kinetics of the molecule is slow, such that release of orthophosphate is delayed, allowing the injected amending solution to disperse and mix throughout the target plume. However, Wellman et al. (2006) demonstrated that rapid agglomeration of Ca-phytate occluded $30 \%$ of the fluid-filled pore space within the formation. Rapid reduction in the hydraulic conductivity will have a significant effect on additional injections of phytic acid solution, the targeted groundwater plume, or both, by deflecting flow from the natural path. Moreover, phytic acid is an organophosphate molecule that would serve as a source of both carbon and phosphorus to the subsurface environment. This may detrimentally serve to biostimulate the oligotrophic subsurface environment present at the Hanford Site.

An alternative to the phosphate amendments previously described is the use of soluble long-chain polyphosphate materials that have been demonstrated to delay the precipitation of phosphate phases (Wellman et al. 2006) (Figure 2.3). Phosphate minerals precipitate when phosphate compounds degrade in water, via hydrolysis, to yield the orthophosphate molecule $\left(\mathrm{PO}_{4}{ }^{3-}\right)$ - the longer the polyphosphate chain, the slower the hydrolysis reaction that leads to orthophosphate production (Figure 2.4).

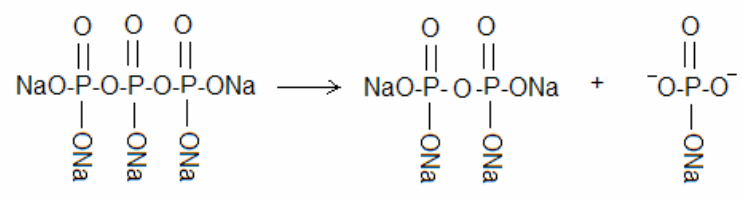

Figure 2.3. Schematic Depicting the Step-Wise Hydrolysis of Sodium Tripolyphosphate 
Accordingly, use of a long-chain polyphosphate compound does not result in a drastic change in the hydraulic conductivity of the target aquifer.

To evaluate the efficacy of a long-chain polyphosphate for in situ immobilization of uranium under hydraulically unsaturated conditions, preliminary laboratory column tests have been conducted at conditions expected within the 300 Area Hanford aquifer. Sediment columns were prepared with Hanford sediments removed from the North Process Pond containing $540 \mathrm{mg} \mathrm{kg}^{-1}$ uranium. The columns were saturated with Hanford groundwater and then desaturated to a water content of $68 \%$. Under unsaturated conditions, the influent solution was switched to a solution of Hanford groundwater spiked with $1,000 \mathrm{ppm}$ of sodium tripolyphosphate. The concentration of uranium in the effluent from the control column (i.e., the influent solution was groundwater without sodium tripolyphosphate), initiated at $\sim 800 \mu \mathrm{g} \mathrm{L}^{-1}$, increased over the first 20 pore volumes to a maximum concentration of $160,000 \mu \mathrm{g} \mathrm{L} \mathrm{L}^{-1}$, and it subsequently exhibited a prolonged

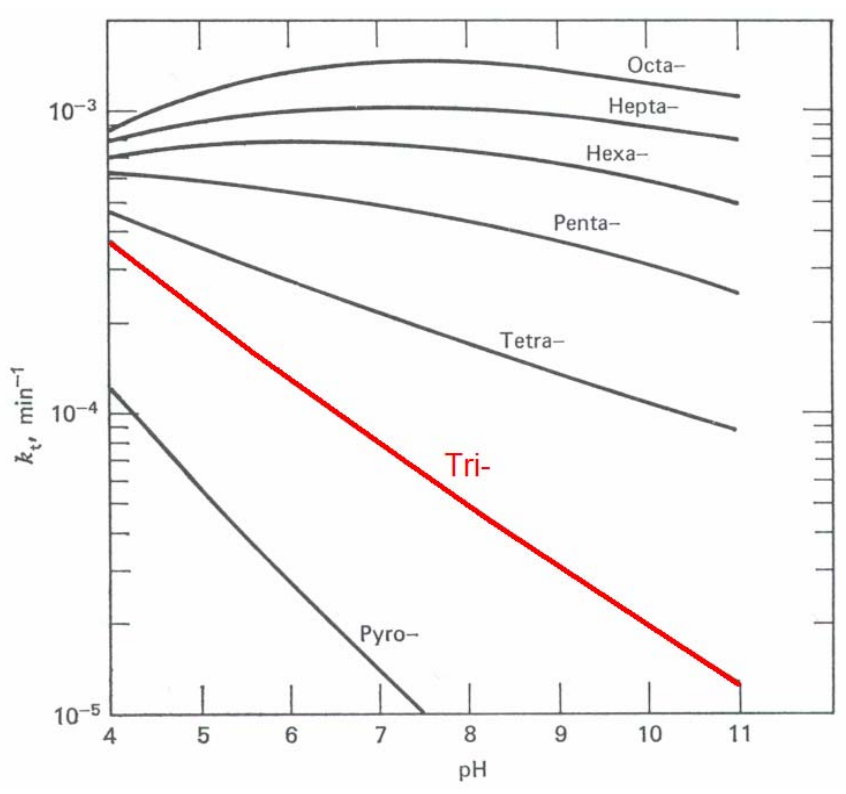

Figure 2.4. Hydrolysis Rate of Polyphosphate Molecules as a Function of $\mathrm{pH}$ (Shen and Morgan 1973) decrease to $1,700 \mu \mathrm{g} \mathrm{L}^{-1}$ over the first 50 pore volumes. The concentration of uranium remains well above the maximum concentration limit (MCL) for uranium during displacement of more than 50 pore volumes of water (Figure 2.5).

Comparatively, the general release behavior of uranium rapidly decreased to concentrations below the drinking water limit in the presence of $1,000 \mathrm{ppm}$ of sodium tripolyphosphate (Figure 2.5). The release of uranium, initiated at approximately $5,000 \mu \mathrm{g} \mathrm{L}^{-1}$, fluctuated over the first 20 pore volumes and subsequently exhibited a rapid decrease to $7 \mu \mathrm{g} \mathrm{L}^{-1}$ within the succeeding 10 pore volumes. Effluent concentrations remained well below drinking water standards through the duration of testing. Furthermore, the aqueous concentration of phosphorus in the column treated with 1,000 ppm of sodium tripolyphosphate was equal to the background concentration until the concentration of uranium began to rapidly decrease. The concentration of phosphorus rapidly increased after approximately 15 pore volumes until reaching a maximum at $\sim 25$ pore volumes. This again suggests that phosphorus is forming uranium-phosphate precipitates with the labile available fraction of uranium within the sediment (Wellman et al. submitted-b). Because autunite sequesters uranium in the oxidized form, U(VI), rather than forcing reduction to U(IV), the possibility of re-oxidation and subsequent re-mobilization of uranium is negated. In addition to autunite, excess phosphorous may result in apatite mineral formation, providing a long-term source of treatment capacity. 


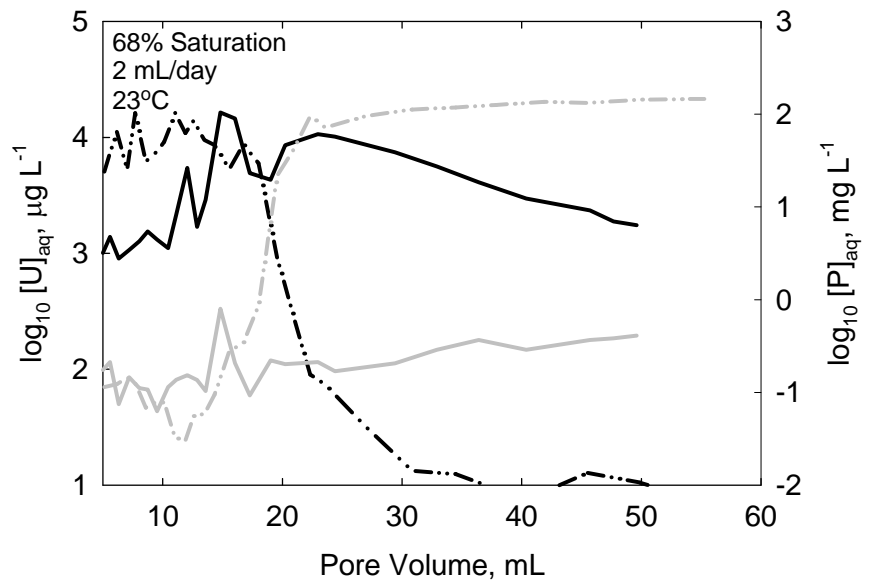

$$
\begin{array}{ll}
-\cdots-\cdots-\cdots & {[U] \text { with } 1000 \text { ppm Sodium Tripolyphosphate }} \\
\hdashline \cdots \cdots-\cdots & {[\mathrm{U}] \text { with } 0 \mathrm{ppm} \text { Sodium Tripolyphosphate }} \\
& {[\mathrm{P}] \text { with } 1000 \text { ppm Sodium Tripolyphosphate }} \\
& {[\mathrm{P}] \text { with } 0 \mathrm{ppm} \text { Sodium Tripolyphosphate }}
\end{array}
$$

Figure 2.5. Experimental Release of Uranium and Breakthrough of Phosphorus in Columns at 68\% Water Content With and Without Soluble Sodium Tripolyphosphate Amendments at a Concentration of $1000 \mathrm{ppm}$ 


\subsection{Objectives}

This experimental plan describes a laboratory testing program to be performed at Pacific Northwest National Laboratory (PNNL) in support of the 300-FF-5 feasibility study. The overall objective of the proposed work is to evaluate and optimize polyphosphate remediation technology for infiltration, either from ground surface or some depth of excavation, providing direct stabilization of uranium within the deep vadose and smear zone above the 300 Area aquifer. Source treatment in the deep vadose zone will accelerate the natural attenuation of uranium to thermodynamically stable uranium-phosphate minerals, enhancing the performance of the proposed polyphosphate remediation within the 300 Area aquifer. Data obtained from this study will be used to develop implementation cost estimates, identify implementation challenges, and investigate the capability of the technology to meet remedial objectives. This information will be used to establish the viability of the method and determine how best to implement the technology in the field. The approach used in this investigation will consist of a combined laboratory and intermediate-scale experimental approach that includes the following elements summarized below. Details regarding the proposed research for these tasks are provided in the following sections. 


\subsection{Laboratory-Scale Testing}

Laboratory-scale tests will be conducted to evaluate technical issues, including the 1) degradation and mobility of polyphosphate amendment under unsaturated conditions, 2) rate and extent of reaction between polyphosphate with calcite-bound uranium, uranium-carbonates, and uranium-silicates under slow and fast infiltration, 3) effect of chemical microenvironments on the degradation of polyphosphate and the formation of autunite, and 4) solubility of autunite under unsaturated conditions. All experiments, except for the autunite solubility measurements, will be conducted with sediments and groundwater from the 300 Area to verify that testing conditions are representative of the remediation area.

\subsection{Behavior of Polyphosphate Amendment under Unsaturated Conditions}

The mobility of phosphate species within subsurface environments is dependent upon the mineralogy and geochemistry of the environment (Akinremi and Cho 1991; Cho 1991; Hsu 1964; Ige et al. 2007; Kuo and Lotse 1972; Kuo and Lotse 1974; Li and Stanforth 2000; Molle et al. 2003; Muljadi et al. 1966; Olsen et al. 1986; Taylor and Gurney 1965). Moreover, the mobility of reactive species within the subsurface has been shown to be highly dependent upon water content (Gamerdinger and Kaplan 2000; Gamerdinger et al. 1998; Gamerdinger et al. 2001b; a; Lindenmeier et al. 1995; McGraw 1996; McGraw and Kaplan 1997; Wellman et al. submitted-a).

The migration of polyphosphate and its degradation products will be quantified as a function of water content within 300 Area vadose zone and smear zone sediments. The data will be analyzed to determine mobile-immobile water domains; consideration will be given to pore-level processes, including film flow, the effects of mobile/immobile water, pore-scale heterogeneity, and preferential flow paths on the mobility of polyphosphate. These hydraulic properties will be considered in predicting the mobility of polyphosphate.

Unsaturated-column experiments will be conducted on an unsaturated flow apparatus (UFA) following standard PNNL-procedures. The experimental centrifugation system and method used to conduct unsaturated transport experiments are described in detail elsewhere (Gamerdinger and Kaplan 2000; Gamerdinger and Kaplan 2001; Gamerdinger et al. 1998; Gamerdinger et al. 2001b; a). Briefly, the UFA instrument consists of a temperature-controlled ultracentrifuge (Model L8-UFA, Beckman Coulter, Inc., Fullerton, CA), which has been modified to provide constant flow to two specimens through a rotating seal assembly (Figure 4.1). Unsaturated columns (length, $L=6.0 \mathrm{~cm}$, radius, $r=2.25 \mathrm{~cm}$, bulk volume, $V_{\text {bulk }}, 95.43 \mathrm{~cm}^{3}$ ) are packed and saturated in the same manner as conventional columns. Columns will be packed with materials from the Hanford vadose zone. Columns will be brought into physical and chemical equilibrium with Hanford groundwater by displacing groundwater through the columns until a minimum of 10 saturated pore volumes have been displaced. These equilibrated columns will then be used in unsaturated experiments at the desired moisture contents to determine polyphosphate breakthrough curves. Hydraulic equilibrium will be established at the desired water content based on the centrifugal force and flow rate. Water contents used in this investigation will span the range of conditions encountered within the 300 Area vadose zone through the smear zone (Table 4.1). 
Table 4.1. Experimental Conditions for the Quantification of Polyphosphate Mobility as a Function of Water Content

\begin{tabular}{||c|c||}
\hline \hline Water Content, $\mathrm{wt} \%$ & $5 \%, 10 \%, 15 \%, 25 \%, 35 \%, 50 \%$ \\
\hline Conservative Tracer & Pentafluorbenzoic Acid (PFBA) \\
\hline$[\mathrm{P}]$ & 1500 ppm as tripolyphosphate, pyrophosphate, and orthophosphate, respectively \\
\hline Temperature, ${ }^{\circ} \mathrm{C}$ & 23 \\
\hline $\mathrm{pH}$ & 7 \\
\hline
\end{tabular}

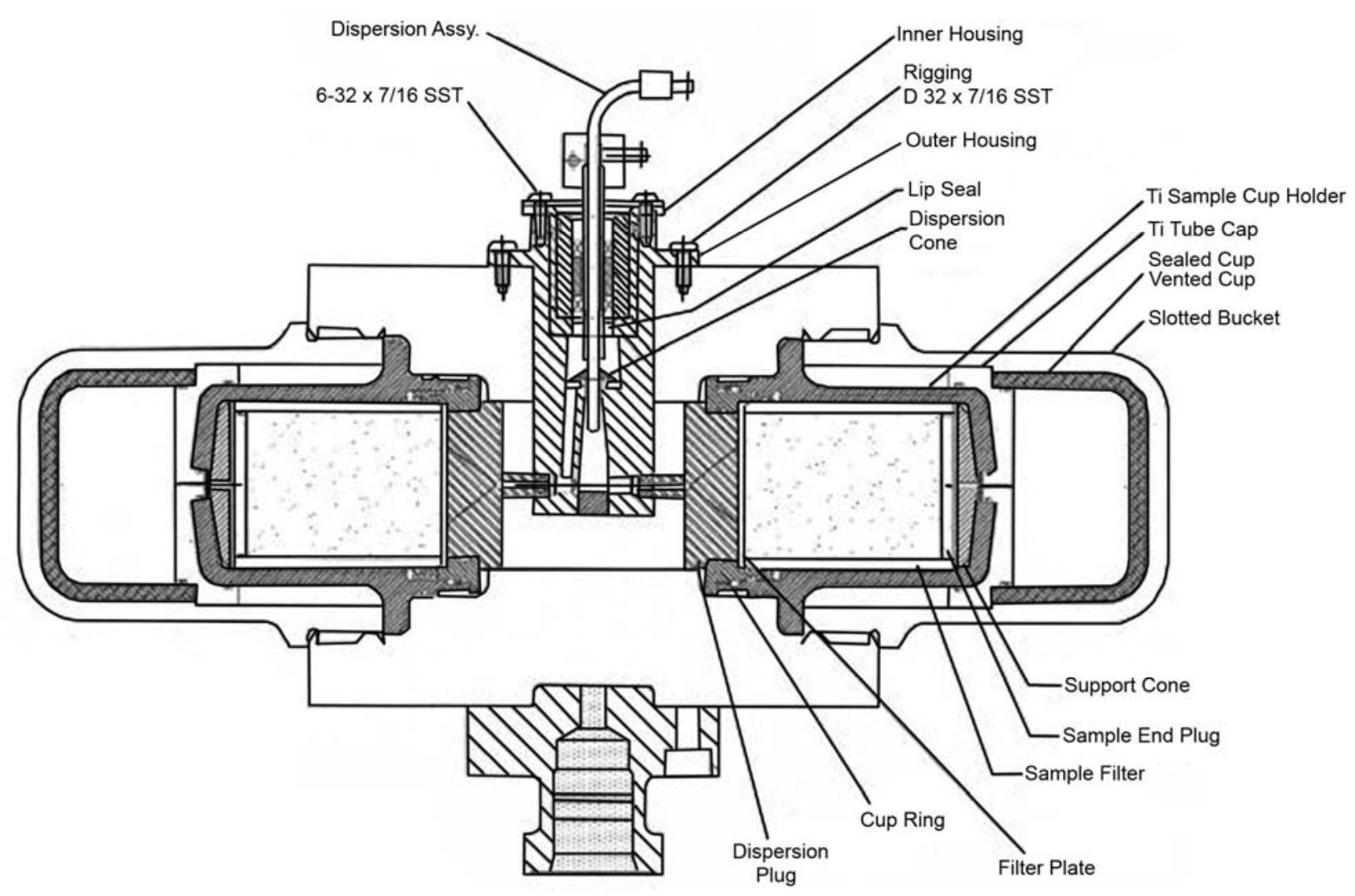

Figure 4.1. Schematic of UFA Constant Flow Rotor and Rotating Seal Assembly

Breakthrough curves will be determined by changing the influent solution to Hanford groundwater spiked with polyphosphate and a non-reactive tracer, such as PFBA or bromide, until complete breakthrough is attained. Subsequently, the influent solution will then be changed to unspiked Hanford groundwater until all polyphosphate has been displaced from the column. The conservative tracer is needed within the influent solution to provide an estimate of the water flow patterns in the columns. It is anticipated, based on previous work, that flow patterns change as a function of saturation (specifically, the proportion of mobile and immobile water in the column will change with saturation). The degree of soil moisture saturation will be determined gravimetrically on a daily basis throughout the experiments. The concentration of phosphorus in the effluent will be measured with ${ }^{31} \mathrm{P}$ nuclear magnetic resonance (NMR) and inductively coupled plasma-optical emission spectrometry (ICP-OES). ICP-OES will be used to 
measure total phosphorus in solution; ${ }^{31} \mathrm{P}$ NMR will be used to quantify the kinetic degradation rate of tripoly- and pyrophosphate molecules during subsurface transport.

Results of this task will quantify the retardation of polyphosphate, the rate of degradation, and the retardation of degradation products as a function of the water content, based on moment analysis of the breakthrough curve and ${ }^{31} \mathrm{P}$ NMR results. These results will be incorporated into the site-specific model to predict the migration of polyphosphate and the respective degradation products within the vadose zone and smear zone.

\subsection{Interaction of Polyphosphate with Calcite-Bound Uranium}

Evaluating the interaction of polyphosphate with calcite-bound uranium (Dong et al. 2005; Zachara et al. 2005) is critical to understanding the potential rate and magnitude of uranium release during remedy infiltration and the rate and mechanism of uranium sequestration via polyphosphate. The transformation of calcite-bound uranium into the uranium-phosphate minerals may occur via two potential mechanisms. First, calcite-bound uranium may be complexed by aqueous polyphosphate. This may accelerate the release of uranium from the calcite phase, resulting in a subsequent aqueous reaction to re-precipitate the uranium as autunite. Alternatively, polyphosphate may sorb to the calcite surface, and a subsequent transformation may occur, resulting in the formation of autunite without releasing uranium into the aqueous phase. This knowledge will allow a more effective design of the infiltration strategy to minimize the mobilization of uranium during remediation.

To determine the stability of uranium-bearing calcite, it is first necessary to characterize the phase and determine whether uranium is bound via sorption or incorporated into the structure. The interaction of uranium with calcite will be evaluated using x-ray absorption spectroscopy, time resolved fluorescence, and Raman spectroscopy. If uranium is partitioned with the calcite phase via a sorption mechanism, static desorption isotherms will be conducted to quantify the reversibility of the partitioning. However, if uranium is incorporated into the calcite structure, the release of uranium will be governed by the solubility of the phase. As such, the solubility will be quantified over a $\mathrm{pH}$ (6 to 9 ) and temperature interval $\left(5^{\circ}, 23^{\circ}, 60^{\circ}\right.$, and $\left.90^{\circ} \mathrm{C}\right)$ using the isopiestic method (Platford 1991; Felmy et al. 1994; Rai et al. 2005). The approach for conducting solubility tests relevant to conditions present within the 300 Area vadose zone and smear zone is further discussed in the following section. Results will be compared to the solubility of uranium-enriched calcite and known uranyl-carbonate compounds (e.g., liebigite $\left[\mathrm{Ca}_{2}\left(\mathrm{UO}_{2}\right)\left(\mathrm{CO}_{3}\right)_{3} \bullet 11 \mathrm{H}_{2} \mathrm{O}\right]$, rutherfordine $\left[\mathrm{UO}_{2} \mathrm{CO}_{3}\right]$, and zellerite $\left.\left[\mathrm{Ca}\left(\mathrm{UO}_{2}\right)\left(\mathrm{CO}_{3}\right)_{2} \bullet 5 \mathrm{H}_{2} \mathrm{O}\right]\right)$ in the presence of polyphosphate.

The interaction of polyphosphate with calcite-bound uranium will be evaluated by determining the effects of geochemical conditions on the partitioning of polyphosphate and its degradation products to calcite, the reversibility of the partitioning, and the coordination geometry of the interaction between polyphosphate and calcite-bound uranium. Static batch tests will be conducted over a narrow $\mathrm{pH}$ range comparable to that expect within the 300 Area, $\mathrm{pH} 6$ to 8 . Isotherms will be developed for polyphosphate and its degradation products to quantify the partitioning of polyphosphate with calcite as a function of $\mathrm{pH}$ (Table 4.2 to Table 4.4). We will use the American Society of Testing Materials (ASTM 2001) standard test methodology for determining $\mathrm{K}_{\mathrm{d}}$ values and the maximum loading capacity of polyphosphate with calcite. The ICP-OES will be conducted according to standard technical procedures developed by PNNL. 
Desorption isotherms will subsequently be conducted to quantify the reversibility of the partitioning. We will use the American Society of Testing Materials (ASTM 2004) standard test methodology for sequential batch extraction.

Table 4.2. Conditions for Quantification of the Kinetic Interaction of Polyphosphate with Calcite-bound Uranium

\begin{tabular}{||c|c||}
\hline Temperature, ${ }^{\circ} \mathrm{C}$ & 23 \\
\hline $\mathrm{pH}$ & $6,6.5,7,7.5,8$ \\
\hline$[\mathrm{P}]$ & $1500 \mathrm{ppm}$ as Tripolyphosphate, pyrophosphate, and orthophosphate, respectively \\
\hline Time, min & $2,4,6,10,15,30,60,120,480,1440$ \\
\hline
\end{tabular}

Table 4.3. Experimental Conditions for Quantifying the Loading of Polyphosphate on Calcite

\begin{tabular}{||c|c||}
\hline \hline Temperature, ${ }^{\circ} \mathrm{C}$ & 23 \\
\hline $\mathrm{pH}$ & $6,6.5,7,7.5,8$ \\
\hline$[\mathrm{P}]$ & $1500 \mathrm{ppm}$ as Tripolyphosphate, pyrophosphate, and orthophosphate, respectively \\
\hline Solution-to-Solid Ratio & $50,100,200,500,1000,5000,10000,20000$ \\
\hline
\end{tabular}

Table 4.4. Experimental Conditions for Quantifying the Partitioning of Polyphosphate with Calcite

\begin{tabular}{||c|c||}
\hline Temperature, ${ }^{\circ} \mathrm{C}$ & 23 \\
\hline $\mathrm{pH}$ & $6,6.5,7,7.5,8$ \\
\hline$[\mathrm{P}]$ & $\begin{array}{r}10 \mathrm{ppb}, 30 \mathrm{ppb}, 100 \mathrm{ppb}, 250 \mathrm{ppb}, 500 \mathrm{ppb}, 1 \mathrm{ppm}, 10 \mathrm{ppm} \text { as Tripolyphosphate, } \\
\text { pyrophosphate, and orthophosphate, respectively }\end{array}$ \\
\hline Solution-to-Solid Ratio & $100: 1$ \\
\hline \hline
\end{tabular}

A duplicate, parallel set of experiments will be conducted to evaluate the coordination geometry of the interaction between polyphosphate and calcite using x-ray absorption spectroscopy, time-resolved fluorescence, and Raman spectroscopy. Scanning electron microscopy (SEM) and transmission electron microscopy (TEM) will also be used to monitor the formation of alteration phases. In addition, the effect of calcite and calcite-bound uranium on the degradation of polyphosphate to orthophosphate, metaphosphate, and tripolyphosphate will be determined as a function of $\mathrm{pH}$ (from 6 to 8 ) with ${ }^{31} \mathrm{P}$ nuclear magnetic resonance spectroscopy. These results will be compared to the results obtained with uraniumenriched calcite (Wang et al. 2005) and pure uranium-carbonate phases (e.g., liebigite, rutherfordine, and zellerite).

The results of this task will identify the mechanism of autunite formation via the reaction of solidphase calcite-bound uranium and aqueous polyphosphate remediation technology. Furthermore, the sitespecific model will be updated with key thermodynamic data, including the kinetics of autunite formation and the degradation of polyphosphate in the presence of calcite and calcite-bound uranium. 


\subsection{Effect of Polyphosphate on Uranium Mineralogy}

Uranyl minerals typically precipitate following the thermodynamic progression of precipitating those that have the lowest solubility, for which precipitation kinetics do not present significant barriers to nucleation. This is followed by precipitating the advanced uranium minerals, which occurs over a considerable time frame (Smith 1984; Finch et al. 1999). The general sequence begins with the uranylhydroxides, followed by the -carbonate, -silicates and finally, the highly stable uranyl-phosphates. Many arid and semiarid environments have exhibited accelerated corrosion of uranium phases due to cycling between wet and dry periods (Finch et al. 1992; Finch and Ewing 1992). Wet-dry cycling increases swelling and cracking of the minerals, resulting in an increase in the amount of reactive surface area. This accelerates weathering of initial uranium minerals and favors the formation of advanced uraniumminerals, such as uranyl-phosphates (Sowder et al. 1999). Evaluating the rate and extent of reaction between polyphosphate and the uranium mineral phases is critical to quantifying the rate and extent of autunite formation for various polyphosphate formulations and the optimum infiltration rate for polyphosphate stabilization of soluble uranium phases present within the 300 Area vadose zone and smear zone. These phases include metatorbernite (Catalano et al. 2004; Zachara et al. 2005), sodium boltwoodite (Zachara et al. 2005; Catalano et al. 2004; Catalano et al. 2006), and uranium rich natural calcite (Wang et al. 2005), which experience wet-dry cycling due to recharge, and they control the availability of uranium within the vadose zone and smear zone, The interaction of the polyphosphate amendment on the stability of uranium phases within the vadose zone and smear zone will be evaluated with static batch and dynamic tests.

Static Tests. Static experiments will be conducted over the temperature range $\left(5^{\circ}, 23^{\circ}, 60^{\circ}\right.$, and $\left.90^{\circ} \mathrm{C}\right)$ as a function of $\mathrm{pH}$, ranging from 6 to 8, in Hanford Site groundwater (Table 4.5). This $\mathrm{pH}$ range is expected to be within the range that bounds the expected treatment-site $\mathrm{pH}$.

Table 4.5. Experimental Conditions for Quantifying the Interaction of Polyphosphate with UraniumBearing Phases

\begin{tabular}{||c|c||}
\hline Temperature, ${ }^{\circ} \mathrm{C}$ & $5,23,60,90$ \\
\hline $\mathrm{pH}$ & $6,7,8$ \\
\hline$[\mathrm{P}]$ & $1500 \mathrm{ppm}$ as Tripolyphosphate \\
\hline Solution-to-Solid Ratio & $100: 1$ \\
\hline Uranium-bearing Phases & Calcite-bound Uranium, metatorbernite, sodium boltwoodite \\
\hline
\end{tabular}

A combination of analytical techniques, including SEM-energy dispersive spectrometry (-EDS), highresolution (HR)-TEM, in situ Raman spectroscopy, X-ray diffraction, (XRD) inductively coupled plasmamass spectrometry (ICP-MS), ICP-OES, and ${ }^{31} \mathrm{P}$ NMR will be used to monitor the degradation of polyphosphate and the degradation and/or transformation of the uranium minerals as well as the build-up and identity of secondary phases. This will be accomplished by monitoring the chemistry of the bulk solution, the formation of alteration phases, and any changes in the surface features and chemical properties of the uranium minerals over time. Static experiments will be started in series with specific samples being earmarked for termination to evaluate the time-dependent changes that occur to the uranium mineral surface, via SEM-EDS and HR-TEM. 
Results of this subtask will elucidate the transformation mechanism, identity of secondary phases, and the kinetics of the reaction between uranyl-carbonate and -silicate minerals with the polyphosphate remedy, as a function of $\mathrm{pH}$, under solubility-limiting conditions. This information will be coupled with the results of dynamic testing (described below) to aid in the understanding and interpretation of how chemical heterogeneities and microenvironments may affect the mechanism and rate of polyphosphate degradation and autunite formation, given the $\mathrm{pH}$-dependence of the reactions.

Dynamic Testing. Dynamic tests will be conducted under unsaturated conditions using the pressurized unsaturated flow (PUF) system (McGrail et al. 1997; 1999; Pierce et al. 2006; Wierenga and Van Genuchten 1989). The UFA and PUF systems are equally suited to conducting comparable unsaturated flow experiments. However, the PUF system allows controlled dynamic changes in water content that simulate the periodic wet-dry cycling experienced in the deep vadose zone and smear zone.

Additionally, slight changes in $\mathrm{pH}$, conductivity, and water content that occur during dissolution and precipitation reactions

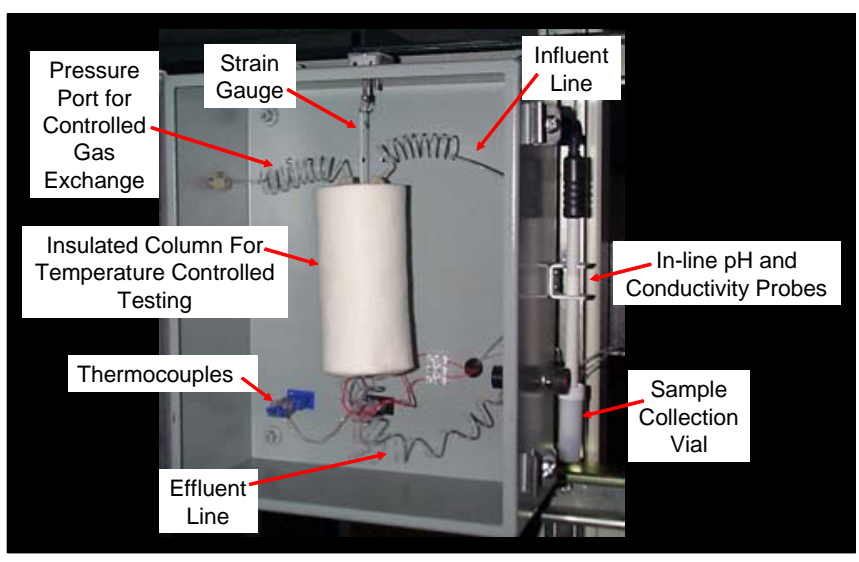

Figure 4.2. Photo of PUF Column Assembly are continuously logged via the PUF system. As such, the PUF system is better suited to conducting unsaturated weathering and precipitation experiments than the UFA system (Pierce et al. 2006; McGrail et al. 1997; 1999) (Figure 4.2).

The PUF system, which is similar to a Wierenga column (McGrail et al. 1997; 1999), consists of a polyetheretherketone column $(r=0.96 \mathrm{~cm}, L=7.62 \mathrm{~cm})$ with a porous titanium plate; it has a nominal pore size of $0.2 \mu \mathrm{m}$ and is sealed in the bottom of the column. Once the porous titanium plate is water saturated, water, but not air, is allowed to flow through the $0.2-\mu \mathrm{m}$ pores, as long as the applied pressure differential does not exceed the air entry relief pressure, referred to as the bubble pressure of the Ti-plate. If the pressure differential is exceeded, air will escape through the plate and compromise the capability to maintain unsaturated flow conditions in the column (McGrail et al. 1997; 1999).

Control columns will be used to evaluate the effect of specific chemical environments, which may influence the mechanism and rate of polyphosphate hydrolysis, and the formation of autunite, given the $\mathrm{pH}$ dependence of the reactions and the effect of reactive surface area for nucleation (Table 4.6).

Table 4.6. Experimental Conditions for Quantifying the Interaction of Polyphosphate with UraniumBearing Phases

\begin{tabular}{||c|c||}
\hline Temperature, ${ }^{\circ} \mathrm{C}$ & 90 \\
\hline $\mathrm{pH}$ & $6,7,8$ \\
\hline Geochemical Microenvironment & Calcite, quartz, iron oxide, plagioclase, feldspar \\
\hline Uranium-bearing Phases & Calcite-bound Uranium, metatorbernite, sodium boltwoodite \\
\hline
\end{tabular}


Control columns will be packed with individual sediments comprising the 300 Area subsurface (e.g., quartz, feldspar, plagioclase, calcite) and distinct uranium phases previously identified as controlling phases in 300 Area sediments (Catalano et al. 2004; Catalano et al. 2006; Dong et al. 2005; Wang et al. 2005; Zachara et al. 2005). The columns will be saturated with Hanford groundwater and then pressurized and drained to the desired water content. This process of fully saturating and reducing the water content to the desired level minimizes preferential flow paths and hysteresis and verifies the most consistent, uniform attainment of water content within a series of unsaturated columns. Following the attainment of hydraulic and chemical equilibrium, the influent solution will be changed to the polyphosphate amendment (Table 4.7).

Table 4.7. Polyphosphate Test Amendment Formulation (Wellman et al. 2007)

\begin{tabular}{|c|c|c|c|c|c|c|c|}
\hline Injection & Amendment & Formula & CAS \# & $\begin{array}{c}\text { Formula } \\
\text { Wt, g/mol }\end{array}$ & $\begin{array}{c}\text { Solubility, g/L } 23^{\circ} \mathrm{C} \\
\mathrm{H}_{2} \mathrm{O}\end{array}$ & $\begin{array}{c}\text { Conc., } \\
\text { g/L }\end{array}$ & Conc., $\mathbf{M}$ \\
\hline \multirow[t]{3}{*}{1} & $\begin{array}{l}\text { Sodium phosphate, } \\
\text { monobasic }\end{array}$ & $\mathrm{NaH}_{2} \mathrm{PO}_{4}$ & 7558-80-7 & 1119.98 & 29.63 & "0.59 & $4.94 \times 10^{-3}$ \\
\hline & Sodium pyrophosphate & $\mathrm{Na}_{4} \mathrm{P}_{2} \mathrm{O}_{7}$ & 7722-88-5 & 265.9 & 32.81 & 0.66 & $2.47 \times 10^{-3}$ \\
\hline & \begin{tabular}{|l|}
$\begin{array}{l}\text { Sodium } \\
\text { tripolyphosphate }\end{array}$ \\
\end{tabular} & $\mathrm{Na}_{5} \mathrm{P}_{3} \mathrm{O}_{10}$ & \begin{tabular}{|l|}
$7758-29-4$ \\
\end{tabular} & 367.86 & 60.40 & 1.21 & $3.29 \times 10^{-3}$ \\
\hline 2 & Calcium chloride & $\mathrm{CaCl}_{2}$ & $10043-52-4$ & 110.98 & 800 & 3.41 & $3.07 \times 10^{-2}$ \\
\hline
\end{tabular}

The effect of wet-dry cycling will be simulated by periodically resaturating the column, with continuous flow, and then desaturating the column to the initial water content. The rate of uranium release and immobilization, identity of uranium phases, and stability of resulting uranium phases will be evaluated as a function of infiltration rate and periodic wet-dry cycling. Effluent samples will be continuously monitored for $\mathrm{pH}$ and conductivity, and the water content of the column will be continuously logged, based on gravimetric measurements. ICP-MS, ICP-OES, flow field flow fractionation (FFF) ICP-MS (Jackson et al. 2005a; Jackson et al. 2005b; Ranville et al. 2007), and ion chromatography-mass spectrometry (IC-MS) will be used to monitor aqueous cation and anion concentrations to monitor the degradation and/or transformation of the uranium minerals as well as the build-up and identity of secondary phases. Upon termination of the column tests, SEM-EDS, HR-TEM, and XRD will be used to evaluate uranium-mineral phase identity and the extent of reaction between uranium-phases and polyphosphate. The thermodynamic database and the reaction code EQ3NR (Wolery and Jarek 2003) will be used to evaluate the uranium aqueous speciation and saturation state of the effluent solutions with respect to uranium solid phases using an updated thermodynamic database for uranium.

Results of solution chemistry analyses from static and control column tests will be used to develop a model to predict the distribution patterns of autunite over time and space, based on the infiltration rate and polyphosphate-amendment formulation. A site-specific set of column tests will be conducted as previously described for the control columns, and they will be composed of sediments collected from the 300 Area. Results of this subtask will quantify the effect of periodic wet-dry cycling on the efficacy of polyphosphate remediation for uranium in the vadose zone and smear zone. The extent and rate of uranium released from 300 Area sediments will be quantified as a function of the infiltration rate of the polyphosphate remedy. Additionally, the rate of uranium immobilization, the identity of uranium phases, and the stability of the resulting uranium phases will be quantified as a function of the infiltration rate. 
Results from static and dynamic tests contained within this task will be incorporated into the site-specific model, allowing predictive simulations of the efficacy of infiltrating polyphosphate remediation technology through the vadose zone and smear zone.

\subsection{Autunite Solubility}

In dynamic systems, the long-term stability of minerals is controlled by the solubility and dissolution rate of the mineral. Under highly advective conditions where transport is greater than the solubility, the stability of the mineral is controlled by dissolution kinetics. Alternatively, in low to moderately advective environments, where the solubility is greater than the rate of mass transport, the long-term stability of the mineral is based on the solubility of the phase. The later conditions are relevant to the 300 Area vadose zone and smear zone. As such, to quantify the long-term stability of autunite and therein the performance of polyphosphate technology, it is necessary to determine the solubility of autunite under hydraulic unsaturated conditions. We will conduct solubility experiments using the isopiestic method, which has been previously described in detail (Felmy et al. 1994; Platford 1991). The water activity is controlled through vapor equilibrium between an isopiestic standard solution and the mineral-electrolyte mixture in a reaction vessel. A distinct advantage in using this apparatus for solubility studies is that one can accurately set the activity of water at any desired value in a mineral-electrolyte mixture by using wellcalibrated isopiestic standards and concurrently controlling reaction temperatures from 373 to $438 \mathrm{~K}$ (Rai et al. 1995).

Solubility measurements will be made over a $\mathrm{pH}$ (6 to 9$)$ and temperature interval $\left(5^{\circ}, 23^{\circ}, 60^{\circ}\right.$, and $90^{\circ} \mathrm{C}$ ). Briefly, the apparatus consists of an evacuated chamber typically containing up to 12 reaction vessels recessed into a heating block constructed of aluminum. We will initially approach equilibrium from the under-saturated direction. After we establish the saturation levels from these experiments, we will conduct solubility experiments that are approached from a supersaturation condition. This approach will avoid a major pitfall of using high degrees of supersaturation that result in the precipitation of kinetically fast-forming metastable phases. The proposed approach of bracketing the equilibrium initially from undersaturation and later from a known degree of supersaturation will help establish a more reliable equilibrium solubility for autunite under hydraulically unsaturated conditions. Since the solutions in equilibrium with the solid phases may be highly concentrated, correction factors to $\mathrm{pH}$ will be applied, in some cases, using the modified Gran titration method (Pitzer and Silvester 1976). Activities of dissolved species will be computed using EQ3/6 chemical equilibrium software that includes ion interaction parameters from Pitzer and Silvester.

Results of this task will establish reliable equilibrium solubility values for autunite under hydraulically unsaturated conditions, allowing accurate prediction of the long-term stability of autunite, and thereby assess the performance of polyphosphate remediation within the vadose zone and smear zone. 


\subsection{Intermediate-Scale Testing}

This section describes the planned intermediate-scale testing, including the effects of sediment type and infiltration characteristics on vadose zone polyphosphate transport. The results of this task will quantify the transport of polyphosphate and degradation products and yield degradation rates at a scale that is bridging the gap between the small-scale UFA studies and the field scale. These results will be used to test and verify a site-specific, variable saturation, reactive transport model and to aid in the design of a pilot-scale field test of this technology.

\subsection{Effects of Sediment Type and Infiltration Characteristics on Vadose Zone Polyphosphate Transport}

Intermediate-scale column tests will be conducted to evaluate the effects of Hanford sediment properties, infiltration type (e.g., ponded, pulsed injection, constant-rate injection), infiltration volume, and polyphosphate concentration on amendment emplacement and efficiency. All experiments will be conducted with Hanford sediments and groundwater from the 300 Area to verify that testing conditions are representative of the remediation area.

The experimental design of the column experiments will be determined based on infiltration and redistribution modeling exercises using the STOMP simulator (White and Oostrom 2006). To obtain independent input parameters for these simulations, the Hanford sediments used in the column experiments will be hydraulically characterized using the Hydraulic Properties Apparatus (HPA), also located in the Subsurface Flow and Transport Laboratory (SFTL), a DOE user facility within the Environmental Molecular Sciences Laboratory (EMSL). The HPA uses a fully automated procedure to determine the hydraulic conductivity with the constant flux, constant head, and falling head methods as well as fluid retention properties using the multi-step method.

Two different $5-\times 5-\mathrm{cm}$ rectangular columns will be used in this study. The first column is $1-\mathrm{m}$ long and is equipped with a Mott-sintered metal lower boundary, allowing the application of negative pressures up to $300 \mathrm{~cm}$. This unique capability allows the representation of vadose zone conditions several meters above a water table. For the second column, which is 2-m long, the water table location can be controlled. This column can be used to study flow and transport in the smear zone and the unsaturated zone directly above this water-saturated region.

A dual-energy gamma radiation system (Oostrom et al. 2003; Oostrom and Lenhard 2003) will be used to determine water saturations during the infiltration and redistributing phases of the experiments. Aqueous samples in the vadose zone will be extracted from wick-type sampling ports placed throughout the flow cells to evaluate the uniformity of the polyphosphate amendment infiltration and migration through the sediment. The sampling extracting system is designed to remove small amounts of fluid from unsaturated porous media with minimal disturbance to the local flow field. At the outlet of the columns, breakthrough curves will be obtained of water-soluble components. Aqueous ion concentrations will be quantified using ICP-MS, ICP-OES, and FFF-ICP-MS. After the experiments are completed, the columns will be carefully excavated. Fluorescence and scanning laser Raman spectroscopy will be used to monitor the in situ formation of autunite and apatite. 
The infiltration experiments will be completed for three representative sediment types, dominated by either silt, sand, or gravel. For each of these sediments, ponded and surface-distributed infiltration techniques (e.g, constant-rate and pulsed) will be tested. Both columns can be used for ponded infiltration tests because of the ability to maintain atmospheric conditions in the gas phase using uniformly spaced venting holes. Besides application type and infiltration rate, the infiltration volume will also be varied. The fourth variable that will be varied in the column experiments is the polyphosphate concentration of the injection solution. The information obtained from the breakthrough curves and the sediment analysis will provide valuable information needed for field vadose zone application of this technique.

The results of this task will quantify the transport of polyphosphate and degradation products and yield degradation rates at a scale that is bridging the gap between the small-scale UFA studies and the field scale. These results will be used to test and verify a site-specific, variable saturation, reactive transport model and to aid in the design of a pilot-scale field test of this technology. In particular, the infiltration approach and monitoring strategy of the pilot test would be primarily based on results from intermediate-scale testing. Tested infiltration approaches will include a ponded application to evaluate conditions where high infiltration rates are deemed most effective and distributed surface applications (e.g., drip emitters, sprinkler system) for lower infiltration rates. 


\subsection{Data Analysis and Reporting}

This work element consists of managing, compiling, and evaluating all of the data generated during the laboratory- and intermediate-scale testing to prepare a final report that can be used in future planning to prepare a treatability test. The final report will cover activities, including laboratory development work, through the intermediate-scale demonstration of the technology. Findings presented in this report will form the basis of an evaluation of this technology for future pilot-scale testing. 


\subsection{Expected Deliverables}

The expected output from this experimental plan is a data package that includes 1) quantification of the retardation of polyphosphate and its degradation products as a function of water content, 2) determination of the rate of degradation under unsaturated conditions, 3) development of an understanding of the mechanism of autunite formation via the reaction of solid-phase calcite-bound uranium and aqueous polyphosphate remediation technology, 4) development of an understanding of the transformation mechanism, identity of secondary phases, and the kinetics of the reaction between uranylcarbonate and -silicate minerals with the polyphosphate remedy under solubility-limiting conditions, 5) quantification of the extent and rate of uranium released and immobilized, based on the infiltration rate of the polyphosphate remedy and the effect of periodic wet-dry cycling on the efficacy of polyphosphate remediation for uranium in the vadose zone and smear zone, and 6) quantification of equilibrium solubility values for autunite under hydraulically unsaturated conditions, allowing accurate prediction of the long-term stability of autunite. Moreover, the results of intermediate scale testing will quantify the transport of polyphosphate and degradation products and yield degradation rates at a scale that is bridging the gap between the small-scale UFA studies and the field scale. These results will be used to test and verify a site-specific, variable-saturation, reactive transport model and to aid in the design of a pilot-scale field test of this technology. In particular, the infiltration approach and monitoring strategy of the pilot test would be primarily based on results from intermediate-scale testing. Results from this experimental plan will be documented in a PNNL report. 


\subsection{Quality Assurance, ES\&H, and Waste-Management Requirements}

\subsection{Quality Assurance}

The work will be conducted in accordance with the Groundwater Project Quality Assurance Plan (PNNL 2006). All instrument calibrations and materials will be traceable, test procedures and associated training activities will be documented in detail, and test methods will comply with established plans and procedures. The Standards-Based Management System (SBMS) subject area "Software" (PNNL 2005) is being followed for data analysis software being used to store, sort, and reduce data.

All staff members contributing to the work specified in this experimental plan will have received proper technical and quality assurance training. The specific technical procedures that will be used are described in Table 8.1:

Staff executing routine analytical procedures shall comply with Hanford Analytical Services Quality Assurance Requirements Documents (HASQARD), Volume 1: Administrative Requirements and Volume 4: Laboratory Technical Requirements, otherwise known as HASQARD (DOE 1998). Any analytical procedural deviations shall be documented in the narrative of the data report with a justification, unless these deviations result from updated versions of the procedures. All data not meeting the quality control (QC) requirements shall be properly noted and the associated QC failures will be documented and reported according to the Nuclear Quality Assurance Requirements Description (NQARD)-1602. Individuals who have not completed the appropriate training will not conduct work.

\subsection{Environmental Safety and Health}

All precautionary measures will be taken to insure that laboratory work will be conducted in a safe manner. Safety glasses, and face shields when appropriate, will be used to protect the eyes and face. Those working with acid will be required to follow the safety practices associated with each acid they are using. Work will be performed in chemical hoods when there is potential for acid spills or the release of noxious vapors. The flow apparatus to be used for these tests is sitting in a plexiglass catch basin so that should a break or leak occur in one or more of the fluid transfer lines, the spill would be contained within the catch basin and could not overflow onto the laboratory floor.

\subsection{Waste Management}

Small amounts of liquid and solid wastes will be generated from the testing conducted under this Test Plan. These wastes managed in accordance with appropriate satellite accumulation in the laboratory. All regulated wastes will be properly disposed per requirements found in PNNL's SBMS Managing Waste (PNNL 2006) subject area procedures. 
Table 8.1. Technical Procedures Used in Designing this Experimental Plan

\begin{tabular}{|c|c|c|c|}
\hline Method & Analysis & "Document Number & " Procedure Title \\
\hline $\begin{array}{l}\text { Inductively coupled plasma- } \\
\text { optical emission spectroscopy } \\
\text { (ICP-OES) }^{\text {(a) }}\end{array}$ & $\begin{array}{l}\mathrm{Ca}, \mathrm{Fe}, \mathrm{K}, \mathrm{Mg}, \mathrm{Mn}, \mathrm{Na}, \\
\mathrm{P}, \mathrm{S}, \mathrm{Si}\end{array}$ & PNNL-AGG-ICP-AES ${ }^{(\mathrm{a})}$ & $\begin{array}{l}\text { Inductively Couple Plasma- } \\
\text { Optical Emission Spectrometry } \\
\text { (ICP-OES) Analysis }\end{array}$ \\
\hline $\begin{array}{l}\text { Inductively coupled plasma- } \\
\text { mass spectroscopy (ICP-MS) }\end{array}$ & $\mathrm{U}$ & PNNL-AGG-415 & $\begin{array}{l}\text { Inductively Coupled Plasma- } \\
\text { Mass Spectrometric (ICP-MS) } \\
\text { Analysis }\end{array}$ \\
\hline Ion chromatography (IC) & $\mathrm{Cl}^{-}, \mathrm{F}^{-}, \mathrm{PO}_{4}^{3-}$ & AGG-IC-001 & $\begin{array}{l}\text { Determinations by Ion } \\
\text { Chromatography (IC) }\end{array}$ \\
\hline $\begin{array}{l}\text { Solid-state } \mathrm{pH} \text { electrode and } \\
\text { meter }\end{array}$ & $\mathrm{pH}$ & AGG-PH-001 & $\mathrm{pH}$ Measurement \\
\hline X-ray diffraction (XRD) & Mineralogy & RPL-XRD-PIP & $\begin{array}{l}\text { Operation of Scintag Pad-V } \\
\text { X-Ray Diffractor (RGD \#62) }\end{array}$ \\
\hline $\begin{array}{l}\text { Scanning Electron } \\
\text { Microscopy/Energy- } \\
\text { Dispersive X-ray } \\
\text { Spectrometry (SEM/EDS) }\end{array}$ & $\begin{array}{l}\text { Particle morphology, } \\
\text { size, and qualitative } \\
\text { elemental analysis }\end{array}$ & PNL-SP-3 & $\begin{array}{l}\text { Scanning Electron } \\
\text { Microscopy/Energy Dispersive } \\
\text { Spectrometry }\end{array}$ \\
\hline Particle-size distribution & Particle size & PNL-MA-567, SA-3 & $\begin{array}{l}\text { Particle-size analysis (pipette or } \\
\text { hydrometer method); wet sieve } \\
\text { analysis will be used to remove } \\
\text { sand-size particle. }\end{array}$ \\
\hline Hydraulic conductivity & $\begin{array}{l}\text { Saturated column } \\
\text { hydraulic conductivity }\end{array}$ & PNL-MA-567, SA-5 & $\begin{array}{l}\text { Falling head hydraulic } \\
\text { conductivity }\end{array}$ \\
\hline Water retention & Water retention & UFA-SK-01 & $\begin{array}{l}\text { Determination of water retention } \\
\text { as a function of water content } \\
\text { using open-flow centrifugation } \\
\text { techniques }\end{array}$ \\
\hline Water content & Water content & PNL-MA-567, SA-7 & Water content \\
\hline Bulk density & Bulk density & PNL-MA-567, SA-8 & Clod density/bulk density \\
\hline Particle density & Particle density & PNL-MA-567, SA-9 & $\begin{array}{l}\text { Determining particle density; } \\
\text { necessary for constant-head } \\
\text { hydraulic conductivity }\end{array}$ \\
\hline Column packing & & $\begin{array}{l}\text { WHC-IP-0635, GEL-3 } \\
\text { Rev. } 3\end{array}$ & $\begin{array}{l}\text { Moisture relationships of soils; } \\
\text { necessary for constant-head } \\
\text { hydraulic conductivity }\end{array}$ \\
\hline $\mathrm{pH} / \mathrm{EC}$ & $\mathrm{pH} / \mathrm{EC}$ & PNL-G-5-pH/EC & $\begin{array}{l}\text { Measuring } \mathrm{pH} / \mathrm{EC} \text { of low-level } \\
\text { radioactive solutions }\end{array}$ \\
\hline $\begin{array}{l}\text { Saturated column } \\
\text { experiments }\end{array}$ & BTCs & AGG-SAT-COL-001 & $\begin{array}{l}\text { Conducting saturated column } \\
\text { experiments }\end{array}$ \\
\hline Batch experiments & & AGG-BSE-001 & Batch sorption experiments \\
\hline Flow-through testing & Weathering Rate & RPL-PIP-SPFT R2 & $\begin{array}{l}\text { Conducting flow-through } \\
\text { experiments }\end{array}$ \\
\hline Surface area & Surface Area & AGG-SA-001 & Measuring surface area \\
\hline UFA & $\begin{array}{l}\text { Unsaturated column } \\
\text { hydraulic conductivity, } \\
\text { fate and transport }\end{array}$ & UFA-SK-01 & $\begin{array}{l}\text { Hydraulic conductivity as a } \\
\text { function of water content using } \\
\text { open-flow centrifugation } \\
\text { techniques }\end{array}$ \\
\hline PUF & $\begin{array}{l}\text { Weathering/Precipitation, } \\
\text { fate and transport }\end{array}$ & AGG-PUF-001 & $\begin{array}{l}\text { Pressurized unsaturated flow } \\
\text { (PUF) apparatus operating } \\
\text { procedure }\end{array}$ \\
\hline
\end{tabular}




\subsection{References}

Akinremi OO, and CM Cho. 1991. "Phosphate Transport in Calium-Saturated Systems: Ii. Experimental Results in a Model System." Soil Science Society of America Journal 55:1282-1287.

Arey JS, JC Seaman, and PM Bertsch. 1999. "Immobilization of Uranium in Contaminated Sediments by Hydroxyapatite Addition." Environmental Science and Technology 33:337-342.

ASTM. 2001. Standard Test Method for Distribution Ratios by the Short-Term Batch Method, D 431993, ASTM International, West Conshohcken, PA.

ASTM. 2004. Standard Test Methods for Sequential Batch Extraction of Waste with Water, D4793-93, American Society for Testing and Materials, Philadelphia, Pennsylvania.

Catalano JG, SC Heald, JM Zachara, and GE Jr. Brown. 2004. "Spectroscopic and Diffraction Study of Uranium Speciation in Contaminated Vadose Zone Sediments from the Hanford Site, Washington State." Environmental Science and Technology 38:2822-2828.

Catalano JG, JP McKinley, JM Zachara, SC Heald, SC Smith, and GE Jr. Brown. 2006. "Changes in Uranium Speciation through a Depth Sequence of Contaminated Hanford Sediments." Environmental Science and Technology 40(8):2517-2524.

Cho CM. 1991. "Phosphate Transport in Calcium-Saturated Systems: I. Theory." Soil Science Society of America Journal 55:1275-1281.

DeFord DH, RW Carpenter, and MW Finan. 1994. 300-Ff-2 Operable Unit Technical Baseline Report, BHI-00012, Rev. 00, Bechtel Hanford, Inc., Richland, Washington.

DOE. 1995. Remedial Investigation/Feasibility Study Report for the 300-Ff-5 Operable Unit, DOE/RL94-85, Rev. 0, U.S. Department of Energy, Richland, Washington.

Dong W, WP Ball, C Liu, Z Wang, AT Stone, J Bai, and JM Zachara. 2005. "Influence of Calcite and Dissolved Calcium on Uranium (VI) Sorption to a Hanford Subsurface Sediment." Environmental Science and Technology 39:7949-7955.

Felmy A, JR Rustad, MJ Mason, and R deLa Bretonne. 1994. A Chemical Model for the Major Electrolyte Components of the Hanford Waste Tanks: The Binary Electrolytes in the System: $\mathrm{Na}_{-} \mathrm{NO}_{3}{ }^{-}$ $\mathrm{NO}_{2}-\mathrm{SO}_{4}-\mathrm{F}-\mathrm{PO}_{4}-\mathrm{OH}-\mathrm{Al}(\mathrm{OH})_{4}-\mathrm{H}_{2} \mathrm{O}$, Westinghouse Hanford Company, Richland, WA.

Finch RJ, EC Buck, PA Finn, and JK Bates. 1999. "Oxidative Corrosion of Spent $\mathrm{UO}_{2}$ Fuel in Vapor and Dripping Groundwater at $90^{\circ} \mathrm{C} . "$ In: 1998 Material Research Society Fall Meeting, Boston, MA.

Finch RJ, and RC Ewing. 1992. "The Corrosion of Uraninite under Oxidizing Conditions." Journal of Nuclear Materials 190:133-156.

Finch RJ, ML Miller, and RC Ewing. 1992. "Weathering of Natural Uranyl Oxide Hydrates: Schoepite Polytypes and Dehydration Effects." Radiochimica Acta 58/59:433-443. 
Gamerdinger AP, and DI Kaplan. 2000. "Application of a Continuous-Flow Centrifugation Method for Solute Transport in Disturbed, Unsaturated Sediments and Illustration of Mobile-Immobile Water." Water Resources Research 36(7):1747-1755.

Gamerdinger AP, and DI Kaplan. 2001. "Physical and Chemical Determinants of Colloid Transport and Deposition in Water-Unsaturated Sand and Yucca Mountain Tuff." Environmental Science and Technology 35:2497-2504.

Gamerdinger AP, DI Kaplan, and CT Resch. 1998. Uranium (VI) Sorption and Transport in Unsaturated, Subsurface Hanford Site Sediments -- Effect of Moisture Content and Sediment Texture: Final Report for Subtask 2b, PNNL-11975, Pacific Northwest National Laboratory, Richland, WA.

Gamerdinger AP, DI Kaplan, DM Wellman, and RJ Serne. 2001a. "Two-Region Flow and Decreased Sorption of Uranium (VI) During Transport in Hanford Groundwater and Unsaturated Sands." Water Resources Research 37(12):3155-3162.

Gamerdinger AP, DI Kaplan, DM Wellman, and RJ Serne. 2001b. "Two-Region Flow and Rate-Limited Sorption of Uranium (Vi) During Transport in an Unsaturated Silt Loam." Water Resources Research 37(12):3147-3153.

Gerber MS. 1992. Past Practices Technical Characterization Study-300 Area-Hanford Site, WHCMR-0388, Westinghouse Hanford Company, Richland, Washington.

Hsu PH. 1964. "Adsorption of Phosphate by Aluminum and Iron in Soils." Soil Science Society Proceedings:474-478.

Ige DV, OO Akinremi, and DN Flaten. 2007. "Direct and Indirect Effects of Soil Properties on Phosphorus Retention Capacity." Soil Science Society of America Journal 71(1):95-100.

Jackson BP, JF Ranville, PM Bertsch, and AG Sowder. 2005a. "Characterization of Colloidal and Humic-Bound Ni and U in The "Dissolved" Fraction of Contaminated Sediment Extracts." Environmental Science and Technology 39:2478-2485.

Jackson BP, JF Ranville, and AL Neal. 2005b. "Application of Flow Field Flow Fractionation-ICPMS for the Study of Uranium Binding in Bacterial Cell Suspensions." Analytical Chemistry 77:1393-1397.

Kuo S, and EG Lotse. 1972. "Kinetics of Phosphate Adsorption by Calcium Carbonate and CaKaolinite." Soil Science Society of America Proceedings 36:725-729.

Kuo S, and EG Lotse. 1974. "Kinetics of Phosphate Adsorption and Desorption by Hematite and Gibbsite." Soil Science 116(6):400-406.

Lee SY, CW Francis, ME Timpson, and MP Elless. 1995. Radionuclide Containment in Soil by Phosphate Treatment, CONF-9503120-1, Oak Ridge National Laboratory, Oak Ridge, TN.

Li L, and R Stanforth. 2000. "Distinguishing Adsorption and Surface Precipitation of Phosphate on Goethite $(\alpha-\mathrm{FeOOH}) . "$ Journal of Colloid and Interface Science 230:12-21. 
Lindenmeier CW, RJ Serne, JL Conca, A Owen, T, and MI Wood. 1995. Solid Waste Leach Characteristics and Contaminant-Sediment Interactions Volume 2: Contaminant Transport under Unsaturated Moisture Contents, PNL-10722, Pacific Northwest National Laboratory, Richland, WA.

McGrail BP, PFC Martin, and CW Lindenmeier. 1997. "Accelerated Testing of Waste Forms Using a Novel Pressurized Unsaturated Flow (PUF) Method." In: Materials Research Society Symposium Proceedings.

McGrail BP, PFC Martin, and CW Lindenmeier. 1999. "Method and Apparatus for Measuring Coupled Flow, Transport, and Reaction Processes under Liquid Unsaturated Flow Conditions." In: Battelle Memorial Institute.

McGraw MA. 1996. Effect of Colloid Size, Colloid Hydrophobicity, and Volumetric Water Content on the Transport of Colloids through Porous Media. Berkeley, CA, University of California - Berkeley.

McGraw MA, and DI Kaplan. 1997. Colloid Suspension Stability and Transport through Unsaturated Porous Media, PNNL-11565, Pacific Northwest National Laboratory, Richland, WA.

Molle P, A Lienard, A Grasmick, and A Iwema. 2003. "Phosphorus Retention in Subsurface Constructed Wetlands: Investigations Focused on Calcareous Materials and Their Chemical Reactions." Water Science and Technology 48(5):75-83.

Moore RC, C Sanchez, J Schelling, J Jones, DR Anderson, F Salas, D Lucero, and K Holt. 2001. BenchScale Testing of in-Situ Formation of Apatite in Hanford Soils for Sorption of Uranium and Technetium, SAND2001-3001, Sandia National Laboratories, Albuquerque, NM.

Muljadi D, AM Posner, and JP Quirk. 1966. "The Mechanism of Phosphate Adsorption by Kaolinite, Gibbsite, and Pseudoboehmite." Journal of Soil Science 17(2):230-237.

Nash K. 1993. "Stability and Stoichiometry of Uranyl Phosphonate Coordination Compounds in Acid Aqueous Solutions." Radiochimica Acta 61:147-154.

Nash K. 1994. "Actinide Phosphonate Complexes in Aqueous Solutions." Journal of Alloys and Compounds 213/214:300-304.

Nash K. 2000. Organophosphorous Reagents in Actinide Separations: Unique Tools for Production, Cleanup and Disposal, ANL/CHM/CP-100858, Argonne National Laboratory, Argonne, IL.

Nash K, EJ Jensen, and MA Schmidt. 1998a. "In-Situ Actinide Immobilization of Actinides for Groundwater Cleanup: Laboratory Demonstration with Soil from the Fernald Environmental Management Project." In: Science and Technology for Disposal of Radioactive Tank Wastes. WW Schultz and NJ Lombardo, Eds., Plenum Press, New York:507-518.

Nash K, MP Jensen, and MA Schmidt. 1997. "Actinide Immobilization in the Subsurface Environment by in-Situ Treatment with a Hydrolytically Unstable Organophosphorous Complexant: Uranyl Uptake by Calcium Phytate." In: International Conference on Actinides, Baden-Baden, Germany.

Nash K, MP Jensen, and MA Schmidt. 1998b. "Actinide Immobilization in the Subsurface Environment by in-Situ Treatment with a Hydrolytically Unstable Organophosphorous Complexant: Uranyl Uptake by Calcium Phytate." Journal of Alloys and Compounds 271-273:257-261. 
Nash K, LR Morse, MP Jensen, EH Appelman, MA Schmidt, S Friedrich, M Redko, and JJ Hines. 1999. Water-Soluble Organophosphorous Reagents for Mineralization of Heavy Metals, ANL/CHM/CP-98479, Argonne National Laboratory, Argonne, IL.

Olsen CR, PD Lowry, SY Lee, IL Larsen, and NH Cutshall. 1986. "Geochemical and Environmental Processes Affecting Radionuclide Migration from a Formerly Used Seepage Trench." Geochimica et Cosmochimica Acta 50:593-607.

Oostrom M, C Hofstee, RJ Lenhard, and TW Wietsma. 2003. "Flow Behavior and Residual Saturation Formation of Injected Carbon Tetrachloride in Unsaturated Heterogeneous Porous Media." Journal of Contaminant Hydrology 64:93-112.

Oostrom M, and RJ Lenhard. 2003. "Carbon Tetrachloride Flow Behavior in Unsaturated Hanford Caliche Material: An Investigation of Residual Napl." Vadose Zone Journal 2:25-33.

Pierce EM, BP McGrail, MM Valenta, and DM Strachan. 2006. "The Accelerated Weathering of a Radioactive Low-Activity Waste Glass under Hydraulically Unsaturated Conditions: Experimental Results from a Pressurized Unsaturated Flow (PUF) Test." Nuclear Technology 155.

Pitzer KS, and LF Silvester. 1976. "Thermodynamics of Electrolytes. Vi. Weak Electrolytes Including $\mathrm{H}_{3} \mathrm{po}_{4}$." Journal of Solution Chemistry 5:269.

Platford RF. 1991. "Experimental Method: Isopiestic." In: Activity Coefficients in Electrolyte Solutions. RM Pytkowicz, Ed., CRC Press, Boca Raton, FL. 1.

Rai D, AR Felmy, SP Juracich, and F Rao. 1995. Estimating the Hydrogen Ion Concentration in Concentrated $\mathrm{NaCl}$ and $\mathrm{Na}_{2} \mathrm{SO}_{4}$ Electrolytes, SAND94-1949, Pacific Northwest National Laboratory, Richland.

Rai D, Y Xia, L Rao, NJ Hess, AR Felmy, DA Moore, and DE McCready. 2005. "Solubility of $\left(\mathrm{UO}_{2}\right)_{3}\left(\mathrm{PO}_{4}\right)_{2}{ }^{*} 4 \mathrm{H}_{2} \mathrm{O}$ in $\mathrm{H}^{+}-\mathrm{Na}^{+}-\mathrm{OH}^{-}-\mathrm{H}_{2} \mathrm{PO}_{4}{ }^{-}-\mathrm{HPO}_{4}{ }^{2-}-\mathrm{PO}_{4}{ }^{3-}-\mathrm{H}_{2} \mathrm{O}$ and Its Comparison to the Analogous $\mathrm{PuO}_{2}{ }^{2+}$ System." Journal of Solution Chemistry 34(4):469-498.

Ranville JF, J Hendry, TN Reszt, Q Xie, and BD Honeyman. 2007. "Quantifying Uranium Complexation by Groundwater Dissolved Organic Carbon Using Asymmetrical Flow Field-Flow Fractionation." Journal of Contaminant Hydrology 91:233-246.

Seaman JC, JS Arey, and PM Bertsch. 2001. "Immobilization of Nickel and Other Metals in Contaminated Sediments by Hydroxyapatite Addition." Journal of Environmental Quality 30:460-469.

Seaman JC, J Hutchinson, BP Jackson, and VM Vulava. 2003. "In Situ Treatment of Metals in Contaminated Soils Using Phytate." Journal of Environmental Quality 32:153-161.

Smith J, D. K. 1984. Uranium Geochemistry, Mineralogy, Geology, Exploration, and Resources. Institute of Mining and Metallurgy, London.

Sowder AG, SB Clark, and RA Fjeld. 1999. "The Transformation of Uranyl Oxide Hydrates: The Effects of Dehydration on Synthetic Metaschoepite and Its Alteration to Becquerelite." Environmental Science and Technology 33:3552-3557. 
Taylor AW, and EL Gurney. 1965. "Precipitation of Phosphate by Iron Oxide and Aluminum Hydroxide from Solutions Containing Calcium and Potassium." Soil Science Society of America Proceedings 29:1823.

Wang Z, JM Zachara, PL Gassman, C Liu, O Qafoku, W Yantasee, and JG Catalano. 2005.

"Fluorescence Spectroscopy of U(VI)-Silicates and U(VI)-Contaminated Hanford Sediment." Geochimica Cosmochimica Acta 69(6):1391-1403.

Wellman DM, AP Gamerdinger, DI Kaplan, and RJ Serne. submitted-a. "Effect of Particle Scale Heterogeneity on Uranium (VI) Retardation During Transport in Unsaturated Porous Media." Vadose Zone Journal.

Wellman DM, JP Icenhower, and AT Owen. 2006. "Comparative Analysis of Soluble Phosphate Amendments for the Remediation of Heavy Metal Contaminants: Effect on Sediment Hydraulic Conductivity." Environmental Chemistry 3:219-224.

Wellman DM, EM Pierce, EL Richards, BC Butler, KE Parker, JN Glovack, SD Burton, SR Baum, ET Clayton, and EA Rodriguez. 2007. Interim Report:Uranium Stabilization through Polyphosphate Injection - 300 Area Uranium Plume Treatability Demonstration Project, PNNL-16683, Pacific Northwest National Laboratory, Richland, WA.

Wellman DM, EM Pierce, and MM Valenta. submitted-b. "Efficacy of Soluble Sodium Tripolyphosphate Amendments for the in Situ Immobilization of Uranium." Environmental Chemistry.

White MD, and M Oostrom. 2006. Stomp Subsurface Transport over Multiple Phases, Version 4.0, User's Guide, PNNL-15782, Pacific Northwest National Laboratory, Richland, WA.

Wierenga PJ, and MT Van Genuchten. 1989. "Solute Transport through Small and Large Unsaturated Soil Columns." Ground water 27(1):35-42.

Wolery TW, and RL Jarek. 2003. Eq3/6, Theoretical Manual, User's Guide, and Related Documentation (Version 8.0), Sandia National Laboratory, Albuquerque, NM.

Wright J, LM Peurrung, TE Moody, JL Conca, X Chen, PP Didzerekis, and E Wyse. 1995. In Situ Immobilization of Heavy Metals in Apatite Mineral Formulations, Pacific Northwest Laboratory, Richland, WA.

Young JS, and JS Fruchter. 1991. Addendum to Data Compilation Task Report for the Source Investigation of the 300-Ff-1 Operable Unit Phase I Remedial Investigations, EMO-1026, Environmental Management Operations for the U.S. Department of Energy, Richland, WA.

Zachara JM, J Davis, C Liu, J McKinley, N Qafoku, DM Wellman, and S Yabusaki. 2005. Uranium Geochemistry in the Vadose Zone and Aquifer Sediments from the 300 Area Uranium Plume, PNNL15121, Pacific Northwest National Laboratory, Richland, WA. 


\section{Distribution}

No. of

Copies

ONSITE

3 DOE-Richland Operations Office

K. M. Thompson

Public Reading Room (2)
No. of

Copies

ONSITE

8 Pacific Northwest National Laboratory

A6-38

$\mathrm{H} 2-53$

$\begin{array}{lr}\text { J. S. Fructher } & \text { K6-96 } \\ \text { D. M Wellman } & \text { K3-62 } \\ \text { E.M. Pierce } & \text { K3-62 } \\ \text { M. Oostrom } & \text { K6-33 } \\ \text { Hanford Technical Library(2) } & \text { P8-55 }\end{array}$

Distr. 1 